\title{
Effect of Nitrogen Growth and Yield of Potato (Solanum tuberosum L.)
}

\author{
Debasis Mahata*, Mayukh Ghosh, Asok saha and Ashis Kumar Singha Roy
}

Department of Agronomy, Uttar Banga Krishi Viswavidyalaya, Pundibari, Cooch Behar, West Bengal-736165, India

*Corresponding author

\begin{tabular}{|l|}
\hline Ke y w o r d s \\
$\begin{array}{l}\text { Potato, Nitrogen, } \\
\text { Yield, Economics }\end{array}$ \\
\hline Article Info \\
\hline $\begin{array}{l}\text { Accepted: } \\
\text { 26 December } 2017 \\
\text { Available Online: } \\
\text { 10 January } 2018\end{array}$ \\
\hline
\end{tabular}

\section{Introduction}

Potato being a short duration crop, fits very well in rice based cropping system even under terai agro-climatic situation of West Bengal where winter is prolonged and kharif rice is harvested even in mid December in low lying situation. There are many factors, which effect the potato production under delayed planting condition, however, nitrogen nutrition is of out 
most importance. Inadequate use of nitrogen decreases potato yield by decreasing plant growth characters. On the contrary, excess nitrogen may also hinder its yield by reducing translocation of photosynthates from top to bottom.

In respect of success in potato cultivation in India starting from the establishment of CPRI in 1935, its cultivation has spread throughout India and more than 80 per cent of its area is concentrated in the Indo-Gangetic plains of which about 74 percent area is in the states of Uttar Pradesh, Bihar and West Bengal and 82 per cent share in the total potato production. Among the states, West Bengal, basically a rice growing area becomes the second largest producer of potato after Uttar Pradesh with their respective production of 133,910 and 135.770 lakh tonnes during 2010-2011 (Horticulture Statistics Division Department of agriculture and Cooperation).

In West Bengal, the total cultivated area under potato was 3.427 lakh hectares during 2010-2011, which was higher than that of 3.158 lakh hectares in the year 2000-2001. Potato production increased at about 2.4 million tonnes from 76.73 lakh tones obtained in the year 2000-2001 to 79.13 lakh tonnes during 2010-2011.

Potato being a short duration crop and for its characteristic features of growing well under wide range of temperature $\left(15^{0}-25^{0} \mathrm{C}\right)$, variable climatic condition, different soil types, $\mathrm{pH}$ ranging from 5.5-7.5 and wide flexibility in planting time, it can be fitted very well in any intensive cropping system. Even in the small farms, can be grown successfully as it can produce bulk in relatively shorter time, which, in turn, could meet up the demands of food for the rapid fast growing populations of the developing countries including India at the time of scares in the decreasing problem of land resources.

\section{Materials and Methods}

The field experiment was carried out at the Instructional farm of Uttar Banga Krishi Viswavidyalaya, Pundibari, Cooch Behar, West Bengal during the rabi season of 200910 and 2010-11. Experiment was laid out in a Randomized Block Design with eight different levels of nitrogen: $75 \mathrm{Kg} \mathrm{N} / \mathrm{ha}\left(\mathrm{T}_{1}\right), 90 \mathrm{Kg} \mathrm{N}$ /ha $\left(\mathrm{T}_{2}\right), 105 \mathrm{Kg} \mathrm{N} / \mathrm{ha}\left(\mathrm{T}_{3}\right), 120 \mathrm{Kg} \mathrm{N} / \mathrm{ha}$ $\left(\mathrm{T}_{4}\right), 135 \mathrm{Kg} \mathrm{N} /$ ha $\left(\mathrm{T}_{5}\right), 150 \mathrm{Kg} \mathrm{N} / \mathrm{ha}\left(\mathrm{T}_{6}\right)$, $165 \mathrm{Kg} \mathrm{N} / \mathrm{ha}\left(\mathrm{T}_{7}\right)$ and $180 \mathrm{Kg} \mathrm{N} / \mathrm{ha}\left(\mathrm{T}_{8}\right)$. The treatments were replicated thrice.

\section{Emergence (\%)}

The emergence $\%$ was calculated from randomly selected rows at 15 and 25 DAP in each plot.

\section{Number of stems plant ${ }^{-1}$}

From the destructive sample of 5 plants the number of tubers plant ${ }^{-1}$ was recorded at 20, 40, 60 days after sowing and at harvest. After taking the destructive samples from each plot, the number of stems plant ${ }^{-1}$ was recorded.

\section{Fresh tuber weight (g plant $\left.{ }^{-1}\right)$}

All the counted tubers from the destructive samples of five plants were separated from stolon and fresh weight of tubers from five plants was measured by electronic balance and the average tuber weight plant $^{-1}$ was worked out at 20,40,60 days after planting and at harvest.

\section{Crop Growth Rate (CGR)}

Crop growth rate can be calculated by the following formula-

$$
\text { CGR }=\frac{W_{2}-W_{1}}{T_{2}-T_{1}} \mathrm{~g} \mathrm{~m}^{-2} \text { day }^{-1}
$$


Where, $\mathrm{W}_{1} \& \mathrm{~W}_{2}$ were the dry weights of the shoot (stem and leaves) at two successive time intervals $T_{1}$ and $T_{2}$ respectively. This is the dry matter accumulation unit ${ }^{-1}$ time and unit ${ }^{-1}$ land area.

\section{Relative Growth Rate (RGR)}

Relative growth rate can be calculated by the following formula-

$$
\begin{gathered}
\log _{\mathrm{e}} \mathrm{W}_{2}-\log _{\mathrm{e}} \mathrm{W}_{1} \\
\mathrm{~T}_{2}-\mathrm{T}_{1}
\end{gathered}
$$

Where, $\mathrm{W}_{1} \& \mathrm{~W}_{2}$ were the dry weight of the plant at two successive time intervals $\mathrm{T}_{1} \& \mathrm{~T}_{2}$ respectively. This is the dry matter accumulation unit ${ }^{-1}$ time and unit ${ }^{-1}$ land area.

\section{Net Assimilation Rate (NAR)}

Net assimilation rate can be calculated by the following formula-

$$
\mathrm{NAR}=\frac{\left(\mathrm{W}_{2}-\mathrm{W}_{1}\right)\left(\log _{\mathrm{e}} \mathrm{L}_{2}-\log _{\mathrm{e}}-\mathrm{L}_{1}\right)}{\left(\mathrm{T}_{2}-\mathrm{T}_{1}\right)\left(\mathrm{L}_{2}-\mathrm{L}_{1}\right)} \mathrm{g} \mathrm{m}^{-2} \mathrm{day}^{-1}
$$

It is expressed as $\mathrm{g}$ of dry matter produced per $\mathrm{mm}^{2}$ of leaf area in a day. Where, $\mathrm{W}_{1} \& \mathrm{~W}_{2}$ were the dry weight of the plant and $L_{1}$ and $L_{2}$ were leaf area at two successive time intervals $\mathrm{T}_{1}$ and $\mathrm{T}_{2}$ respectively. This is the dry matter accumulation unit ${ }^{-1}$ time and unit ${ }^{-1}$ land area.

Tuber Bulking Rate (TBR)

TBR was calculated as:-

$$
\text { TBR }=\frac{W_{2}-W_{1}}{T_{2}-T_{1}}
$$

Where, $\mathrm{W}_{1} \& \mathrm{~W}_{2}$ are the dry weights of tubers in unit area of land at two successive time intervals $T_{1} \& T_{2}$, respectively. Tuber bulking rate (TBR) in $\mathrm{gm}^{-2}$ day $^{-1}$ between 30-40 days,
40-60 days,60-80 days and between 80 and harvest were calculated and mean results were presented in the table.

\section{Cost of cultivation}

This is supplementary index to indicate the amount of capital resources needed to adopt particularly cropping system. Even one system gives higher gross/net income; the farmer may choose another system with less profit which also involves less capital investment because of their limited capital resources. In preparing the cost of cultivation, it is customary to indicate the expenditure incurred on different items such as labour (including family labour), seeds, chemicals (fertilizer and pesticides) and power (tractor and power tiller and pumping water) etc. This will help the farmer to choose a system which uses the resources he has in plenty but demands less on the resources he lacks.

\section{Economics analysis}

The total cost of cultivation was calculated considering the expenditure on land preparation, seed material, sowing, weeding, gap filling and cost of fertilizer, manures, plant protection, harvesting etc. and bacterial inoculation depending upon the particulars of treatments of different crops. The return:cost ratio was calculated by dividing total product value with total cost of cultivation against each treatment.

Total return from one ha.

\section{Return to cost ratio $=$}

Total cost of cultivation

\section{Result and Discussion}

\section{Effect of nitrogen on emergence (\%)}

The results of the emergence percentage for different treatments observed at 15 , and at 25 DAP were presented in the Table 1. 
The results showed that there was significant difference in emergence percentage at all the stages of recording observation with the different levels of nitrogen. It was recorded maximum (59.10 and 92.84\% during 2009-10) with the level of $120 \mathrm{~kg} \mathrm{~N} \mathrm{ha}^{-1}$ and minimum (40.33 and $82.36 \%$ during 2009-10) with the $\mathrm{N}$ level of $180 \mathrm{~kg} \mathrm{~N} \mathrm{ha}^{-1}$ at 15 and at 25 DAP. Moreover, it was recorded maximum (59.69 and $93.77 \%$ during 2010-11) with the level of $120 \mathrm{~kg} \mathrm{~N} \mathrm{ha}{ }^{-1}$ and minimum (40.33 and $83.18 \%$ during 2010-11) with the $\mathrm{N}$ level of $180 \mathrm{~kg} \mathrm{~N} \mathrm{ha}^{-1}$ at 15 and at $25 \mathrm{DAP}$.

The poor emergence was mainly due to late planting and low night temperature (below $15^{\circ} \mathrm{C}$ ) prevailed during the time of observation. Similar result was observed by Brajesh and Ezekiel (2001).

\section{Effect of nitrogen on number of stem plant $^{-1}$}

The results of the number of stem plant ${ }^{-1}$ for different treatments observed at 20, 40 and at 60 DAP were presented in the Table 2.

The results showed that there was significant difference in number of stem plant ${ }^{-1}$ at all the stages of recording observation with the different levels of nitrogen. It was recorded maximum $(2.00,3.00$ and 6.00 during 200910) with the level of $120 \mathrm{~kg} \mathrm{~N} \mathrm{ha}^{-1}$ and minimum (1.33, 1.99 and 3.98 during 200910) with the $\mathrm{N}$ level of $180 \mathrm{~kg} \mathrm{~N} \mathrm{ha}^{-1}$ at 20,40 and at 60 DAP. Moreover, it was recorded maximum $(2.25,3.37$ and 6.74 during 201011) with the level of $120 \mathrm{~kg} \mathrm{~N} \mathrm{ha}^{-1}$ and minimum (1.42, 2.13 and 4.26 during 201011) with the $\mathrm{N}$ level of $180 \mathrm{~kg} \mathrm{~N} \mathrm{ha}^{-1}$ at 20,40 and at 60 DAP.

Anabousi et al., (1997) reported that potato were given $0,125,250$ or $375 \mathrm{~kg} \mathrm{~N} \mathrm{ha}^{-1}$ and resulted significant increase in plant height, stem number plant ${ }^{-1}$. It was also found that increasing Nitrogen application rates upto 250 $\mathrm{kg} \mathrm{N}^{-1}$ resulted significant increases in large and medium tuber yields and reduction in tuber dry matter.

Veer et al., (2002) observed the effects of Nitrogen $(75,100,125,150$ and $175 \mathrm{~kg} \mathrm{~N}$ $\mathrm{ha}^{-1}$ ) on the bulking rates of potato cv. Kufri Sutlej. Plant height, number of stems hill ${ }^{-1}$, leaf fresh weight, number of tubers hill ${ }^{-1}$, dry matter content, yield of different grade tubers, mean total tuber yield and tuber bulking increased with increasing rates of $\mathrm{N}$.

\section{Effect of nitrogen on crop growth rate (g $\mathrm{m}^{-2} \operatorname{day}^{-1}$ )}

The results of the crop growth rate (CGR) for different treatments observed at 20-40 and at 41-60 DAP were presented in the Table 3.

The results showed that there was significant difference in emergence percentage at all the stages of recording observation with the different levels of nitrogen. It was recorded maximum (3.90 and 9.50 during 2009-10) with the level of $120 \mathrm{~kg} \mathrm{~N}^{-1}$ and minimum (2.34 and 2.27 during 2009-10) with the $\mathrm{N}$ level of $180 \mathrm{~kg} \mathrm{~N} \mathrm{ha}^{-1}$ at 20-40 and at 41-60 DAP. Moreover, it was recorded maximum (3.94 and 9.60 during 2010-11) with the level of $120 \mathrm{~kg} \mathrm{~N} \mathrm{ha}^{-1}$ and minimum (2.36 and 2.29 during 2010-11) with the $\mathrm{N}$ level of $180 \mathrm{~kg} \mathrm{~N}$ $\mathrm{ha}^{-1}$ at 20-40 and at 41-60 DAP.

Patel et al., (2000) reported that application of different doses of nitrogen at the rate of 180 , 220 and $260 \mathrm{~kg} \mathrm{ha}^{-1}$ and the highest dry weight of shoots and tubers plant ${ }^{-1}$, LAI, CGR and NAR were recorded at $260 \mathrm{~kg} \mathrm{~N} \mathrm{ha}^{-1}$.

The higher crop growth rate among the cultivars might be due to higher leaf area indices and higher dry matter accumulation. The result corroborated the findings of Fernando (1958). 
The crop growth rate was initially low, reached its peak between 41-60 days after planting due to the increased accumulation of dry matter which resulted in an increase in crop growth rate value with all the cultivars. Furthermore, the dry matters increased linearly upto 60 days after planting in each cultivar. So, the crop growth rate was found to be highest between 41 and 60 days after planting. The result corroborated the findings of Fernando (1958).

Effect of nitrogen on relative growth rate (g $\mathrm{g}^{-1}$ day $^{-1}$ )

The results of the relative growth rate $\left(\mathrm{g} \mathrm{g}^{-1}\right.$ day $^{-1}$ ) for different treatments observed at 20-
40 and at 41-60 DAP were presented in the Table 4. The results showed that there was significant difference in relative growth rate ( $\mathrm{g}$ $\left.\mathrm{g}^{-1} \mathrm{day}^{-1}\right)$ at all the stages of recording observation with the different levels of nitrogen. It was recorded maximum (0.171 and 0.076 during 2009-10) with the level of 120 $\mathrm{kg} \mathrm{N} \mathrm{ha}{ }^{-1}$ and minimum $(0.137$ and 0.044 during 2009-10) with the $\mathrm{N}$ level of $180 \mathrm{~kg} \mathrm{~N}$ $\mathrm{ha}^{-1}$ at 20-40 and at 41-60 DAP. Moreover, it was recorded maximum $(0.173$ and 0.077 during 2010-11) with the level of $120 \mathrm{~kg} \mathrm{~N}$ $\mathrm{ha}^{-1}$ and minimum (0.138 and 0.044 during 2010-11) with the $\mathrm{N}$ level of $180 \mathrm{~kg} \mathrm{~N}^{-1}$ at 20-40 and at 41-60 DAP. Similar result was found by Hruska and Chloupek (1973) and Midmore and Prange (1992).

\begin{tabular}{|l|l|l|l|l|l|l|}
\hline \multirow{2}{*}{ Treatments } & \multicolumn{3}{|c}{ Table.1 Effect of nitrogen on emergence (\%) } \\
& 20-40DAP & $41-60 \mathrm{DAP}$ & $20-40 \mathrm{DAP}$ & $41-60 \mathrm{DAP}$ & $20-40 \mathrm{DAP}$ & $41-60 \mathrm{DAP}$ \\
\hline T1 & 40.26 & 85.25 & 40.66 & 86.10 & 40.46 & 85.68 \\
\hline T2 & 42.85 & 87.57 & 43.28 & 88.45 & 43.06 & 88.01 \\
\hline T 3 & 45.65 & 88.50 & 46.11 & 89.39 & 45.88 & 88.94 \\
\hline T 4 & 59.10 & 92.84 & 59.69 & 93.77 & 59.40 & 93.30 \\
\hline T 5 & 54.23 & 91.23 & 54.77 & 92.14 & 54.50 & 91.69 \\
\hline T 6 & 43.33 & 90.36 & 43.76 & 91.26 & 43.55 & 90.81 \\
\hline T 7 & 41.30 & 83.39 & 41.71 & 84.22 & 41.51 & 83.81 \\
\hline T 8 & 40.33 & 82.36 & 40.73 & 83.18 & 40.53 & 82.77 \\
\hline S.Em. (+) & 0.0346 & 0.0262 & 0.0686 & 0.0475 & 0.0516 & 0.0369 \\
\hline C.D. (0.05) & 0.1050 & 0.0795 & 0.2082 & 0.1441 & 0.1566 & 0.1118 \\
\hline
\end{tabular}

\begin{tabular}{|l|c|c|c|c|c|c|}
\hline \multirow{2}{*}{ Treatments } & \multicolumn{2}{|c|}{ Table.2 Effect of nitrogen on number of stem plant } \\
& 20-40DAP & 41-60DAP & 20-40DAP & 41-60DAP & 20-40DAP & 41-60DAP \\
\hline T1 & 1.47 & 2.20 & 4.40 & 1.57 & 2.35 & 4.70 \\
\hline T2 & 1.57 & 2.35 & 4.70 & 1.69 & 2.53 & 5.06 \\
\hline T 3 & 1.77 & 2.65 & 5.30 & 1.87 & 2.80 & 5.60 \\
\hline T 4 & 2.00 & 3.00 & 6.00 & 2.25 & 3.37 & 6.74 \\
\hline T 5 & 1.87 & 2.80 & 5.60 & 2.00 & 3.00 & 6.00 \\
\hline T 6 & 1.67 & 2.50 & 5.00 & 1.75 & 2.62 & 5.24 \\
\hline T 7 & 1.55 & 2.32 & 4.64 & 1.63 & 2.44 & 4.88 \\
\hline T 8 & 1.33 & 1.99 & 3.98 & 1.42 & 2.13 & 4.26 \\
\hline S.Em. ( + ) & 0.0147 & 0.0510 & 0.0449 & 0.0146 & 0.0189 & 0.0470 \\
\hline C.D. (0.05) & 0.0446 & 0.1548 & 0.1363 & 0.0443 & 0.0572 & 0.1424 \\
\hline
\end{tabular}




\section{Table.3 Effect of nitrogen on crop growth rate $\left(\mathrm{g} \mathrm{m}^{-2}\right.$ day $\left.^{-1}\right)$}

\begin{tabular}{|c|c|c|c|c|c|c|}
\hline \multirow[t]{2}{*}{ Treatments } & \multicolumn{2}{|c|}{ 2009-2010 } & \multicolumn{2}{|c|}{$2010-2011$} & \multicolumn{2}{|c|}{ Pooled } \\
\hline & 20-40DAP & 41-60DAP & 20-40DAP & 41-60DAP & 20-40DAP & 41-60DAP \\
\hline $\mathrm{T1}$ & 2.42 & 4.94 & 2.44 & 4.99 & 2.43 & 4.96 \\
\hline $\mathrm{T} 2$ & 2.44 & 6.22 & 2.46 & 6.28 & 2.45 & 6.25 \\
\hline T 3 & 2.54 & 6.94 & 2.57 & 7.01 & 2.55 & 6.97 \\
\hline $\mathrm{T} 4$ & 3.90 & 9.50 & 3.94 & 9.60 & 3.92 & 9.55 \\
\hline T 5 & 3.36 & 8.68 & 3.39 & 8.77 & 3.38 & 8.72 \\
\hline T 6 & 3.18 & 6.12 & 3.21 & 6.18 & 3.20 & 6.15 \\
\hline T 7 & 2.40 & 3.23 & 2.42 & 3.26 & 2.41 & 3.25 \\
\hline T 8 & 2.34 & 2.27 & 2.36 & 2.29 & 2.35 & 2.28 \\
\hline S.Em. (+) & 0.0308 & 0.1164 & 0.0288 & 0.1050 & 0.0298 & 0.1107 \\
\hline C.D. (0.05) & 0.0935 & 0.3529 & 0.0873 & 0.3185 & 0.0904 & 0.3357 \\
\hline
\end{tabular}

\section{Table.4 Effect of nitrogen on relative growth rate $\left(\mathrm{g} \mathrm{g}^{-1} \mathrm{day}^{-1}\right)$}

\begin{tabular}{|l|l|l|l|l|l|l|}
\hline \multirow{2}{*}{ Treatments } & \multicolumn{2}{|c|}{ 2009-2010 } & \multicolumn{2}{c|}{ 2010-2011 } & \multicolumn{2}{c|}{ Pooled } \\
\cline { 2 - 7 } & 20-40DAP & $41-60 D A P$ & $20-40 D A P$ & $41-60 D A P$ & $20-40 D A P$ & $41-60 D A P$ \\
\hline T1 & 0.141 & 0.042 & 0.142 & 0.042 & 0.142 & 0.042 \\
\hline T2 & 0.145 & 0.049 & 0.146 & 0.049 & 0.146 & 0.049 \\
\hline T 3 & 0.150 & 0.053 & 0.152 & 0.054 & 0.151 & 0.053 \\
\hline T 4 & 0.171 & 0.076 & 0.173 & 0.077 & 0.172 & 0.076 \\
\hline T 5 & 0.162 & 0.073 & 0.164 & 0.074 & 0.163 & 0.073 \\
\hline T 6 & 0.151 & 0.059 & 0.153 & 0.060 & 0.152 & 0.059 \\
\hline T 7 & 0.139 & 0.047 & 0.140 & 0.047 & 0.140 & 0.047 \\
\hline T 8 & 0.137 & 0.044 & 0.138 & 0.044 & 0.138 & 0.044 \\
\hline S.Em. (†) & 0.0054 & 0.0011 & 0.0023 & 0.0044 & 0.0039 & 0.0028 \\
\hline C.D. (0.05) & 0.0165 & 0.0035 & 0.0070 & 0.0134 & 0.0118 & 0.0085 \\
\hline
\end{tabular}

\section{Table.5 Effect of nitrogen on net assimilation rate $\left(\mathrm{g} \mathrm{m}^{-2}\right.$ day $\left.^{-1}\right)$}

\begin{tabular}{|c|c|c|c|c|c|c|}
\hline \multirow[t]{2}{*}{ Treatments } & \multicolumn{2}{|c|}{ 2009-2010 } & \multicolumn{2}{|c|}{ 2010-2011 } & \multicolumn{2}{|c|}{ Pooled } \\
\hline & 20-40DAP & 41-60DAP & 20-40DAP & 41-60DAP & 20-40DAP & 41-60DAP \\
\hline $\mathrm{T} 1$ & 2.85 & 1.72 & 2.88 & 1.74 & 2.86 & 1.73 \\
\hline $\mathrm{T} 2$ & 2.67 & 1.49 & 2.70 & 1.50 & 2.68 & 1.50 \\
\hline T 3 & 3.60 & 2.42 & 3.64 & 2.44 & 3.62 & 2.43 \\
\hline T 4 & 4.64 & 3.12 & 4.69 & 3.15 & 4.66 & 3.14 \\
\hline T 5 & 3.72 & 2.65 & 3.76 & 2.68 & 3.74 & 2.66 \\
\hline T 6 & 3.59 & 2.52 & 3.63 & 2.55 & 3.61 & 2.53 \\
\hline T 7 & 1.98 & 0.95 & 2.00 & 0.96 & 1.99 & 0.95 \\
\hline T 8 & 1.72 & 0.70 & 1.74 & 0.71 & 1.73 & 0.70 \\
\hline S.Em. (土) & 0.0354 & 0.0890 & 0.1105 & 0.0514 & 0.0730 & 0.0702 \\
\hline C.D. (0.05) & 0.1073 & 0.2700 & 0.3351 & 0.1558 & 0.2212 & 0.2129 \\
\hline
\end{tabular}




\begin{tabular}{|c|c|c|c|c|c|c|}
\hline \multirow[t]{2}{*}{ Treatments } & \multicolumn{2}{|c|}{ 2009-2010 } & \multicolumn{2}{|c|}{$2010-2011$} & \multicolumn{2}{|c|}{ Pooled } \\
\hline & 20-40DAP & 41-60DAP & 20-40DAP & 41-60DAP & 20-40DAP & 41-60DAP \\
\hline T1 & 39.45 & 55.25 & 39.84 & 55.80 & 39.65 & 55.53 \\
\hline $\mathrm{T} 2$ & 40.32 & 56.22 & 40.72 & 56.78 & 40.52 & 56.50 \\
\hline T 3 & 48.76 & 58.21 & 49.25 & 58.79 & 49.00 & 58.50 \\
\hline $\mathrm{T} 4$ & 52.55 & 63.21 & 53.08 & 63.84 & 52.81 & 63.53 \\
\hline T 5 & 51.06 & 62.33 & 51.57 & 62.95 & 51.32 & 62.64 \\
\hline T 6 & 42.32 & 61.43 & 42.74 & 62.04 & 42.53 & 61.74 \\
\hline $\mathrm{T} 7$ & 38.41 & 52.37 & 38.79 & 52.89 & 38.60 & 52.63 \\
\hline T8 & 37.39 & 50.12 & 37.76 & 50.62 & 37.58 & 50.37 \\
\hline S.Em. ( $( \pm)$ & 0.0196 & 0.0561 & 0.0293 & 0.0968 & 0.0245 & 0.0765 \\
\hline C.D. (0.05) & 0.0594 & 0.1700 & 0.0890 & 0.2936 & 0.0742 & 0.2318 \\
\hline
\end{tabular}

\begin{tabular}{|l|l|l|l|}
\multicolumn{4}{|c|}{ Table.7 Effect of nitrogen on final yield $\left(\mathrm{t} \mathrm{ha}^{-1}\right)$} \\
\hline Treatments & $2009-2010$ & $2010-2011$ & Pooled \\
\hline T1 & 17.01 & 17.42 & 17.22 \\
\hline T2 & 18.84 & 19.32 & 19.08 \\
\hline T 3 & 19.56 & 20.07 & 19.82 \\
\hline T 4 & 21.46 & 22.04 & 21.75 \\
\hline T 5 & 20.47 & 21.01 & 20.74 \\
\hline T 6 & 16.82 & 17.23 & 17.03 \\
\hline T 7 & 13.88 & 14.18 & 14.03 \\
\hline T 8 & 11.32 & 11.53 & 11.43 \\
\hline S.Em. $(+)$ & 0.0607 & 0.0205 & 0.0406 \\
\hline
\end{tabular}

\section{Table. 8 Economics of cultivation of potato 2009-2010}

\begin{tabular}{|l|l|l|l|l|l|l|}
\hline Treatment & $\begin{array}{l}\text { Tuber } \\
\text { Yield } \\
\text { (t/ha) }\end{array}$ & $\begin{array}{l}\text { Market Price } \\
\text { at Harvest } \\
\text { (Rs./t) }\end{array}$ & $\begin{array}{l}\text { Gross } \\
\text { Return } \\
\text { (Rs.) }\end{array}$ & $\begin{array}{l}\text { Cost of } \\
\text { Cultivation } \\
\text { (Rs.) }\end{array}$ & $\begin{array}{l}\text { Net Return } \\
\text { (Rs.) }\end{array}$ & R : C Ratio \\
\hline T1 & 17.01 & 4500.00 & 76545.00 & 64348.18 & 12196.82 & 0.19 \\
\hline T2 & 18.84 & 4500.00 & 84780.00 & 64533.39 & 20246.61 & 0.31 \\
\hline T 3 & 19.56 & 4500.00 & 88020.00 & 64717.01 & 23302.99 & 0.36 \\
\hline T 4 & 21.46 & 4500.00 & 96570.00 & 64902.22 & 31667.78 & 0.49 \\
\hline T 5 & 20.47 & 4500.00 & 92115.00 & 65085.84 & 27029.16 & 0.42 \\
\hline T 6 & 16.82 & 4500.00 & 75690.00 & 65269.47 & 10420.53 & 0.16 \\
\hline T 7 & 13.88 & 4500.00 & 62460.00 & 65454.68 & -2994.68 & -0.05 \\
\hline T 8 & 11.32 & 4500.00 & 50940.00 & 65638.25 & -14698.3 & -0.22 \\
\hline
\end{tabular}


Effect of nitrogen on net assimilation rate (g m ${ }^{-2}$ day $^{-1}$ )

The results of the net assimilation rate $\left(\mathrm{g} \mathrm{m}^{-2}\right.$ day $^{-1}$ ) for different treatments observed at 2040 and at 41-60 DAP were presented in the Table 5 .

The results showed that there was significant difference in net assimilation rate $\left(\mathrm{g} \mathrm{m}^{-2}\right.$ day $^{-1}$ ) at all the stages of recording observation with the different levels of nitrogen. It was recorded maximum (4.64 and 3.12 during 2009-10) with the level of $120 \mathrm{~kg}$ $\mathrm{N} \mathrm{ha}^{-1}$ and minimum (1.72 and 0.70 during 2009-10) with the $\mathrm{N}$ level of $180 \mathrm{~kg} \mathrm{~N} \mathrm{ha}^{-1}$ at 20-40 and at 41-60 DAP. Moreover, it was recorded maximum (4.69 and 3.15 during 2010-11) with the level of $120 \mathrm{~kg} \mathrm{~N} \mathrm{ha}^{-1}$ and minimum (1.74 and 0.71 during 2010-11) with the $\mathrm{N}$ level of $180 \mathrm{~kg} \mathrm{~N} \mathrm{ha}^{-1}$ at 20-40 and at 41-60 DAP. Pravin et al., (2001) reported the existence of distinct varietal differences in net assimilation rate.

\section{Effect of cultivars on tuber bulking rate (fresh weight basis) $\left(\mathrm{g} \mathrm{m}^{-2} \mathrm{~d}^{-1}\right)$}

The results of the tuber bulking rate (TBR) for different treatments observed at 20-40 and at 41-60 DAP were presented in the Table 6.

The results showed that there was significant difference in emergence percentage at all the stages of recording observation with the different levels of nitrogen. It was recorded maximum (52.55 and 63.21 during 2009-10) with the level of $120 \mathrm{~kg} \mathrm{~N}^{-1}$ and minimum (37.39 and 50.12 during 2009-10) with the $\mathrm{N}$ level of $180 \mathrm{~kg} \mathrm{~N} \mathrm{ha}^{-1}$ at 40-60 and at $61-80$ DAP. Moreover, it was recorded maximum (53.08 and 63.84 during 2010-11) with the level of $120 \mathrm{~kg} \mathrm{~N}^{-1}$ and minimum $(37.76$ and 50.62 during 2010-11) with the $\mathrm{N}$ level of $180 \mathrm{~kg} \mathrm{~N} \mathrm{ha}{ }^{-1}$ at 40-60 and at 61-80 DAP. Similar results was also obtained by Ivin and
Bremner (1965) who reported that tuber bulking rate increased with increasing values of leaf area index.

Veerana et al., (1997) reported that tuberbulking rate was greatest with $100 \%$ of the recommended dose $\left(125 \mathrm{~kg} \mathrm{~N}: 100 \mathrm{~kg} \mathrm{P}_{2} \mathrm{O}_{5}\right.$ : $125 \mathrm{~kg} \mathrm{~K}_{2} \mathrm{O} \mathrm{ha}{ }^{-1}$ ).

Nandi et al., (2002) reported that tuber bulking rate increased with increasing fertilizer rates upto $240 \mathrm{~kg} \mathrm{~N} \mathrm{ha}^{-1}, 200 \mathrm{~kg} \mathrm{P}$ $\mathrm{ha}^{-1}$ and $200 \mathrm{~kg} \mathrm{~K} \mathrm{ha}^{-1}$ and increasing the fertilizer rate up to $300 \mathrm{~kg} \mathrm{~N}^{-1}, 250 \mathrm{~kg} \mathrm{P}$ $\mathrm{ha}^{-1}$ and $250 \mathrm{~kg} \mathrm{~K}_{2} \mathrm{O} \mathrm{ha}^{-1}$ had no beneficial effect and in most cases exhibited declining trends.

\section{Effect of nitrogen on final yield $\left(\mathrm{tha}^{-1}\right)$}

The results of the final yield $\left(\mathrm{t} \mathrm{ha}^{-1}\right)$ for different treatments observed at 2009-10 and 2010-11 were presented in the Table 7.

The results showed that there was significant difference in final yield $\left(\mathrm{t} \mathrm{ha}^{-1}\right)$ in tubers at all the stages of recording observation with the different levels of nitrogen. It was recorded maximum (21.46 tha ${ }^{-1}$ during 2009-10) with the level of $120 \mathrm{~kg} \mathrm{~N}^{-1}$ and minimum (11.32 $\mathrm{t} \mathrm{ha}^{-1}$ during 2009-10) with the $\mathrm{N}$ level of $180 \mathrm{~kg} \mathrm{~N} \mathrm{ha}^{-1}$ at the time of harvest. Moreover, it was recorded maximum $(22.04 \mathrm{t}$ $\mathrm{ha}^{-1}$ during 2010-11) with the level of $120 \mathrm{~kg}$ $\mathrm{N} \mathrm{ha}^{-1}$ and minimum (11.5 tha $\mathrm{turing}^{-1}$ 201011) with the $\mathrm{N}$ level of $180 \mathrm{~kg} \mathrm{~N} \mathrm{ha}^{-1}$ at the time of harvest.

Kleinkopf et al., (1981) reported that Nitrogen was applied at 170, 440 and570 kg available $\mathrm{N} \mathrm{ha}{ }^{-1}$. Maximum daily tuber growth rate was 0.9-1.3 $\mathrm{t} \mathrm{ha}^{-1}$. High levels of available $\mathrm{N}$ at planting delayed linear tuber growth by 7-10 days with minor effects on determinant $\mathrm{cv}$. 
Juzl (1989) reported that potatoes were given 60,120 or $180 \mathrm{~kg} \mathrm{~N} \mathrm{ha}^{-1}$ and result showed that $120 \mathrm{~kg} \mathrm{~N} \mathrm{ha}^{-1}$ was recommended but tuber yield were similar at higher $\mathrm{N}$ level.

Soaud et al., (1990) reported that potatoes were given $0,150-180$ and $270-300 \mathrm{~kg} \mathrm{~N} \mathrm{ha}^{-1}$ and high Nitrogen did not give significantly higher yield.

Ramnik et al., (1999) reported that tuber yield increased with increase in nitrogen levels.

Sud et al., (1999) reported that tuber yield of Kufri Jyoti was increased with increasing Nitrogen rate when it was applied with 0,60 , 120 or $180 \mathrm{~kg} \mathrm{~N} \mathrm{ha}^{-1}$ at Kufri, Himachal Pradesh.

\section{Economics of cultivation of potato}

From the economic point of view (Table 8) the maximum net return of Rs 31667.78 and benefit cost ratio (0.49) was observed in the treatment $T_{4}$ followed by the treatment $T_{5}$ giving net return of Rs. 27029.16 and return cost ratio $(0.42), \mathrm{T}_{4}$ having the highest return cost ratio at 2009-10. From the table 8 it can be seen that the same trend was followed in the next year i.e. 2010-11 with the maximum net return of Rs 34277.78 and benefit cost ratio $(0.53)$ was observed in the treatment $T_{4}$ followed by the treatment $\mathrm{T}_{5}$ giving net return of Rs. 29459.16 and return cost ratio (0.45). So, we can say that at $\mathrm{T}_{4}$ the maximum return could be found and at $T_{7}$ and $T_{8}$ higher dose of nitrogen gave negative impact on yield and gave the lowest returns.

\section{References}

Anabousi, O.A.N., Hattar, B.I. and Suwwan, M.A. 1997. Effect of rate and source of nitrogen on growth, yield and quality of potato under Jordan Valley conditions. Dirasat Agric. Sci. 24(2): 242-259.
Brajesh S and Ezekiel R. 2010. Isopropyl n(3-chlorophenyl) carbamate (CIPC) residues in potatoes stored in commercial cold stores in India. Potato Res. 53:111-120.

Fernando, L. H. 1958. Studies on leaf growth: effect of mineral nutrients and the interdependence of the leaves of a plant. Ph.D., Thesis, Univ. London.

Hruska, L. and Chloupek, O. 1973. Some data on yield formation for different plant densities. Nektere poznalky tvorvy Vynosupri ruzne organizaci porostu. Vedecke prace Vyzkumneho ustavu Bramborarskcho V. Havlickove Brode. 5:101-108.

Juzl, M. 1989. An assessment of yield in very early potato plants at different rates of nitrogen fertilizer. Acta Univ. Agri. Facultas Agronomic. 37(3-4):115-122.

Kleinkopf, G.E., Westermann, D.T. and Dwelle, R.B. 1981. Dry matter production and nitrogen utilization by six potato cultivars. Agron. J. 73(5): 799-802.

Midmore, D. J. and Prange, R. K. 1992. Growth responses of two Solanum species to contrasting temperatures and irradiance levels: relations to photosynthesis, dark respiration and chlorophyll fluorescence. Annals-ofBotany; 69(1): 13-20.

Nandi, P.D. Mandal and D.C. Ghosh. 2002. Fertility management in seedling tuber production from true potato seed (TPS). Hort. J. 15(3): 43-52.

Pravin, Prakash; Chetti, M. B. and Patil, S. S. 2001. Effect of plant growth regulators on growth parameters and yield in potato. Karnataka Journal of Agricultural Sciences; 14(4): 938-942.

Ramnik, Sharma., Dubey, Y.P., Kaistha, B.P. and Sharma, R. 1999. Influence of irrigation and nitrogen on yield, total water expense and water expense efficiency of potato in Lahaul valley of 
Himalayas. J. Indian Soc. Soil Sci. 47 (1): 19-22.

Soaud, A.A., Hofman, G. and Cleemput-OVan Cleemput-O. 1990. Nitrogen fertilization and potato growth. Pedologic. 40 (3): 257-271.

Sud, K.C., Verma, B.C. and Sharma, R.C. 1999. Nitrogen and sulphur role in potato (Solanum tuberosum) nutrition on brown hill soil of Shimla. Indian J.Agric. Sci. 69 (2): 118-121.

Veer, Kumar., Narendra, Singh., Malik, Y.S.,
Bhatia, A.K., Nehra, B.K., Kumar, V. and Singh, N. 2002. Effect of nitrogen and crop duration on bulking behaviour of potato cv. Kufri Sutlej. Haryana J. Hort. Sci. 31 (3-4): 259-261.

Veeranna, H.K., Abdul, Khalak., Krishnamurthy, N., Mudalagiriyappa. and Khalak, A. 1997. Effect of spacing and fertilizer levels on ware potato yield and quality of tubers obtained through 'TPS' seedlings. Indian Agric. 41 (1): 31-36.

\section{How to cite this article:}

Debasis Mahata, Mayukh Ghosh, Asok saha and Ashis Kumar Singha Roy. 2018. Effect of Nitrogen Growth and Yield of Potato (Solanum tuberosum L.). Int.J.Curr.Microbiol.App.Sci. 7(01): 3311-3320. doi: https://doi.org/10.20546/ijcmas.2018.701.394 